\title{
Synthesis and Photophysical Properties of Low Symmetrical Porphyrin-Amino Acid Conjugates and Their Zn Complexes
}

\author{
A. Lyubimtsev, ${ }^{\mathrm{a} @ ~ A . ~ S e m e i k i n, ~}{ }^{\mathrm{a}}$ N. Zheglova $^{\mathrm{a}}{ }^{\mathrm{V}}$ V. Sheinin, ${ }^{\mathrm{b}}$ O. Kulikova, ${ }^{\mathrm{b}}$ and S. Syrbu ${ }^{\mathrm{b}}$ \\ Dedicated to Professor Oleg Aleksandrovich Golubchikov \\ on the occasion of his 70-th birthday
}

${ }^{a}$ Research Institute of Macroheterocycles, Ivanovo State University of Chemistry and Technology, 153000 Ivanovo, Russia

${ }^{\mathrm{b}}$ G.A. Krestov Institute of Solution Chemistry of the Russian Academy of Sciences, 153045 Ivanovo, Russia

${ }^{\circledR}$ Corresponding authorE-mail: alexlyubimtsev@mail.ru

\begin{abstract}
A series unsymmetrical amino acid substituted porphyrins and their Zn-complexes were synthesized and full characterized by ${ }^{1} H$ NMR and UV-Vis spectroscopy and MALDI-TOF spectrometry. Starting with meso-tetraphenylporphyrin $\left(H_{2}\right.$ TPP) 1, porphyrin 2 with one nitro group was synthesized via regioselective nitration reaction. Reduction of the 5-(4'-nitrophenyl)-10,15,20-tris(phenyl)porphine 2 and coupling of obtained 5-(4'-aminophenyl)-10,15,20tris(phenyl)porphine 3 with Boc-protected glycine, L-phenylalanine, L- and D-leucine and L-isoleucine gave the porphyrin-amino acid conjugates $4 a-e$. These free porphyrin ligands 4 were metallized with Zn(II) to form corresponding Zn-complexes 5a-e. Photostability of the ligands 4 and their Zn-complexes 5 and their ability to singlet oxygen generation were studied. All investigated porphyrin-amino acid conjugates show a higher efficiency to generate singlet oxygen than $\mathrm{H}_{2}$ TPP under the same experimental conditions.
\end{abstract}

Keywords: Porphyrin, amino acid, conjugates, Zn-complexes, photostability, singlet oxygen generation.

\section{Синтез и фотофизические свойства низкосимметричных конъюгатов порфиринов с аминокислотами и их цинковых комплексов}

\author{
А. Аюбимцев, ${ }_{1}{ }^{@}$ А. Семейкин, ${ }^{a}$ Н. Жеглова, ${ }^{a}$ В. Шейнин, ${ }^{\text {b }}$ О. Куликова, ${ }^{\mathrm{b}}$ \\ С. Сырбу
}

а НИИ химии макрогетероциклических соединений, Ивановский государственный химико-технологический университет, 153000 Иваново, Россия

${ }^{\mathrm{b}}$ Институт химии растворов РАН им. Г.А. Крестова, 153045 Иваново, Россия

${ }^{\circledR}$ E-mail: alexlyubimtsev@mail.ru

\begin{abstract}
Синтезированы и охарактеризованы методами ${ }^{1}$ Н ЯМР, электронной спектроскопии и масс-спектрометрии (MALDI-TOF) несимметрично замещенные порфирины с остатками аминокислот. Мононитрофенилтрифенилпорфирин 2 получен региоселективным нитрованием 5,10,15,20-тетрафенилпорфина (H,TPP) 1. Восстановлением 5-(4'-нитрофенил)-10,15,20-трифенилпорфина 2 и последующей конденсацией полученного 5-(4'-аминофенил)-10,15,20-трифенилпорфина 3 с Вос-защищенными глицином, L-фенилаланином, Lu D-лейцином и L-изолейцином получены соответствующие конъюгаты порфиринов с аминокислотами 4а-е и их ициновые комплексы 5а-е. Изучены фотостабильность свободных лигандов и металлокомплексов и возможность генерации ими синглетного кислорода. Показана более высокая способность генерирования синглетного кислорода для синтезированных соединений по сравнению с $\mathrm{H}_{2}$ ТPР.
\end{abstract}

Ключевые слова: Порфирин, аминокислоты, коньюгаты, цинковые комплексы, фотостабильность, генерация синглетного кислорода. 


\section{Introduction}

Photodynamic antimicrobial chemotherapy (PACT) as a part of photodynamic therapy (PDT) is a new modality based on selection accumulation of photosensitizers (PS) such as porphyrin in tumor tissues..$^{[1-3]}$ The fundamental process of both PDT and PACT is the energy transfer from light to oxygen to produce reactive oxygen species (ROS). Porphyrins, due to their unique photophysical and photochemical properties, have a special relevance in these fields of medicine and in photodiagnosis. With the aim to increase the biological effectiveness of porphyrins as PS's their conjugation with different biomolecules have been investigated in recent years. The porphyrin conjugates with sugars are in absolute majority. ${ }^{[4]}$ Some porphyrins coupled with amino acids have been also reported to have interesting characteristic for PDT. ${ }^{[5-11]}$ The porphyrin-amino acid conjugates were synthesized via coupling reaction of the mesophenylporphyrins containing from one to four aminophenyl fragments with protected (Boc or Fmoc) amino acids or by coupling meso-carboxyphenylporphyrins with amino acids. Only one example of the second approach was found. [7] The first strategy is most common for the preparation of the porphyrin conjugates with amino acids. This strategy based on activation of the amino acids carboxylic group before their reaction with aminophenylporphyrins. Dicyclohexylcarbodiimide (DCC) is known as most used coupling agent. This DCC method has some drawbacks such as more complicated procedure because of formation of dicyclohexylurea (DCHU) as byproduct, thus an addition 1-hydroxybenzotriazole (HOBt) and its derivatives to DCC were proposed for better product yields. Another reagents for amide bond formation such as 1-ethyl-3-(3'-dimethylaminopropyl) carbodiimide (EDC) etc. with some additions and also their combination were used for amidoporphyrins preparation. The detail list of coupling agents for peptide synthesis was published in 2003 by Marder and Albericio. ${ }^{[12]}$ Here we present the synthetic approaches of preparation a few porphyrin-amino acid conjugates 4a-e and the study of these ligands and their Zn-complexes photostability and ability to singlet oxygen generation.

\section{Experimental}

\section{General}

Boc-protected glycine, $L$-phenylalanine, $L$ - and $D$-leucine, $L$-isoleucine, all solvents and basic materials are commercially available and were used without further purification. 5-(4'-Nitrophenyl)10,15,20-tris(phenyl)porphine 2 and 5-(4'-aminophenyl)-10,15,20tris(phenyl)porphine $\mathbf{3}$ were synthesized as described earlier. ${ }^{[13]}$ UV-Vis spectra were recorded with a Shimadzu UV-1800 spectrophotometer. Mass spectra were recorded on Shimadzu Biotech AXIMA Confidence Linear/Reflectron MALDI-TOF Mass Spectrometer. All samples were run with $\alpha$-cyano-4-hydroxycinnamic acid (CHCA) and 2,5-dihydroxybenzoic acid (DHB) as the matrix or without matrix. Proton nuclear magnetic resonance spectra ( ${ }^{1} \mathrm{H}$ NMR) were recorded on a Bruker Avance III 500 spectrometer $(500.17 \mathrm{MHz}$ for $1 \mathrm{H})$ at $294 \mathrm{~K}$ in deuterated chloroform (with TMS as the internal standard). Thin layer chromatography (TLC) was performed on POLYGRAM® SIL G/UV ${ }_{254}$ plates. Photosta- bility and singlet oxygen generation were studied with dual channel fiber optic spectrophotometrical fluorimeter AvaSpec-2048-2 (Avantes, Nederland's) in $1 \mathrm{~cm}$ optical cuvette using $N, N$-dimethylformamide (DMF) (PanReac, max. $0.01 \%$ water) as the solvent with the LED lamp irradiation $(3 \mathrm{~W}, 110 \mathrm{~lm})$. For study of the singlet oxygen generation the cut off filter with $\lambda<500 \mathrm{~nm}$ additional was used.

Fluorescencequantumyields $\left(\Phi_{\mathrm{F}}\right)$ were determinedby comparative methods, ${ }^{[13]}$ Equation (1), using 5,10,15,20-tetrakis(phenyl)porphine $\left(\mathrm{H}_{2} \mathrm{TPP}\right)\left(\Phi_{\mathrm{F}}=0.11\right)^{[14]}$ and $\mathrm{Zn}(\mathrm{II}) 5,10,15,20$-tetrakis(phenyl) porphine $(\mathrm{ZnTPP})\left(\Phi_{\mathrm{F}}=0.033\right)^{[15]}$ in $(\mathrm{DMF})$ as a standard.

$$
\phi_{F}=\phi_{F}^{S t d} \frac{F A^{S t d} n^{2}}{F^{S t d} A\left(n^{S t d}\right)^{2}}
$$

where $\mathrm{F}$ and $\mathrm{F}^{\mathrm{Std}}$ are the areas under the fluorescence curves for sample and standard, respectively; A and $\mathrm{A}^{\text {Std }}$ are the absorbances of the sample and reference at the excitation wavelength, respectively; $n$ and $n^{\text {Std }}$ are the refractive indices of the solvent used for the sample and standard, respectively.

Singlet oxygen generation and photostability studies. The photostability of the photosensitizers was determined by irradiating $2 \mathrm{ml}$ of porphyrins solutions in DMF (absorbance at Soret band wavelength was 1) with white light. The irradiation was carried out with a LED lamp (3 W, $110 \mathrm{~lm})$ perpendicular to the direction of measurement. At fixed time intervals, the concentration of the porphyrin was determined by visible absorption spectrophotometry. The production of singlet oxygen was established qualitatively using 1,3-diphenylisobenzofuran (DPBF) as a singlet oxygen quencher. To completely cut off the region of DPBF absorption a light filter with $\lambda<500 \mathrm{~nm}$ was used. The decay of the DPBF absorption at $416 \mathrm{~nm}$ was detected after each 10 seconds. Measured absorbance was corrected by the absorbance of the sensitizer at the detection wavelength. Experiment was carried out at least three times for each investigated photosensitizer. UV-Vis spectra were recorded in automatic mode with an interval of 10 seconds using dual channel fiber optic spectrometer AvaSpec-2048-2 (Avantes, Nederland's).

\section{Synthesis}

Synthesis of the 5-(4'-N-tert-butyloxycarbonylglycylamidophenyl)-10,15,20-triphenylporphine 4a. Method A. ${ }^{[16]}$ A mixture of $250 \mathrm{mg}$ (0.4 mmol) 5-(4'-aminophenyl)-10,15,20-triphenylporphine $3,154 \mathrm{mg}(0.9 \mathrm{mmol}) \mathrm{N}$-(tert-butoxycarbonyl)glycine, $173 \mathrm{mg}$ (0.85 mmol) 1-(3'-dimethylaminopropyl)-3-ethylcarbodiimide hydrochloride, and $0.1 \mathrm{ml}(0.44 \mathrm{mmol})$ triethylamine in $80 \mathrm{ml}$ of dichloromethane was stirred at $0{ }^{\circ} \mathrm{C}$ for $1 \mathrm{~h}$. The reaction mixture was allowed to warm up to room temperature and then was stirred for $3 \mathrm{~h}$. The solvent was evaporated to dryness and the residue was purified by flash chromatography using DCM as the eluent. Yield: $310 \mathrm{mg}$ (75 \%). MS (MALDI TOF) $\mathrm{m} / \mathrm{z}$ : Calc. 786.33 for $\mathrm{C}_{51} \mathrm{H}_{42} \mathrm{~N}_{6} \mathrm{O}_{3}$. Found $787.22[\mathrm{M}+\mathrm{H}]^{+}$. UV-Vis (DMSO) $\lambda_{\text {max }}$ (loge) nm: 421 (5.59), 516 (4.26), 551 (3.73), 647 (3.71); $\left(\mathrm{CHCl}_{3}\right)$ $\lambda_{\max }(\log \varepsilon) \mathrm{nm}: 418$ (5.66), 516 (4.25), 551 (3.96), 591 (3.79), 647 (3.70). ${ }^{1} \mathrm{H}$ NMR $\left(\mathrm{CDCl}_{3}\right) \delta_{\mathrm{H}} \mathrm{ppm}: 8.88-8.82(\mathrm{~m}, 8 \mathrm{H}, \beta-\mathrm{H}), 8.21(\mathrm{~d}$, ${ }^{3} J=7 \mathrm{~Hz}, 6 \mathrm{H}, 2^{\prime}, 6^{\prime}-\mathrm{Ph}$ ), 8.18 (d, $\left.J=8 \mathrm{~Hz}, 2 \mathrm{H}, 2^{\prime}, 6^{\prime}-\mathrm{PhGly}\right), 7.94$ (d, $J=8 \mathrm{~Hz}, 2 \mathrm{H}, 3^{\prime}, 5^{\prime}-\mathrm{PhGly}$ ), 7.80-7.71 (m, 9H, 3', 4', 5'-Ph), 5.31 (brs, $1 \mathrm{H},-\mathrm{NHCO}), 4.10$ (d, $\left.J=6 \mathrm{~Hz}, 2 \mathrm{H},-\mathrm{CH}_{2}-\right), 1.57$ (s, 9H, H-t-Bu), $-2.78(\mathrm{~s}, 2 \mathrm{H},-\mathrm{NH})$.

Method B. To a solution of $154 \mathrm{mg}(0.9 \mathrm{mmol})$ of $\mathrm{N}$-(tertbutoxycarbonyl)glycine and $117 \mu \mathrm{l}(0.84 \mathrm{mmol})$ of triethylamine in $80 \mathrm{ml}$ of dichloromethane $77.7 \mu \mathrm{l}(0.816 \mathrm{mmol})$ of ethyl chloroformate was added at $0{ }^{\circ} \mathrm{C}$. Then to a mixture 5-(4'-aminophenyl)-10,15,20-triphenylporphine 3 (250 mg, 0.4 mmol) was added. The reaction mixture was stirred at this temperature overnight. The isolation and purification were done as described for Method $A$ giving the 5-(4'-N-tert-butyloxycarbonyl 
glycinaminophenyl)-10,15,20-triphenylporphine 4a in more than $99 \%$ yield. The ${ }^{1} \mathrm{H}$ NMR and MS (MALDI TOF) spectra were similar with spectra of the compound prepared by Method $A$.

General procedure to synthesis porphyrin-amino acid conjugates $4 \boldsymbol{b}-\boldsymbol{e} .^{[17]}$ A mixture of corresponding amounts of aminophenylporphyrin 3, corresponding Boc-protected amino acids, of DMAP and of EDC in $15 \mathrm{ml}$ of anhydrous dichloromethane was magnetically stirred for $1.5 \mathrm{~h}$ with cooling in an ice bath and then at ambient temperature until the completion of the reaction according to TLC. The resulting solution was subjected to column chromatography on silica with methylene chloride as an eluent. The eluate was evaporated and the porphyrins were precipitated with methanol.

5-[4'-(N-tert-Butyloxycarbonyl-L-phenylalanylamido) phenyl]-10,15,20-triphenylporphine $4 \boldsymbol{b}$. The porphyrin $\mathbf{4 b}$ was obtained by general procedure from $50 \mathrm{mg}(0.08 \mathrm{mmol})$ of porphyrin 3, $46 \mathrm{mg}(0.173 \mathrm{mmol})$ of $N$-tert-butyloxycarbonyl- $L$-phenylalanine, $11 \mathrm{mg}(0.09 \mathrm{mmol})$ of DMAP and $97 \mathrm{mg}(0.508 \mathrm{mmol})$ of EDC. The reaction time was 3 days. Yield: $57 \mathrm{mg}(82.5 \%)$. $R_{f}=0.63$ (benzene-methanol 10:1). MS (MALDI TOF) $m / z$ : Calc. 876.38 for $\mathrm{C}_{58} \mathrm{H}_{48} \mathrm{~N}_{6} \mathrm{O}_{3}$. Found $877.5417[\mathrm{M}+\mathrm{H}]^{+}$. IR $(\mathrm{KBr}) v \mathrm{~cm}^{-1}$ : 1640 (CONH). UV-Vis $\lambda_{\max }$ (lge) nm: 420 (5.66), 517 (4.27), 554 (3.99), 591 (3.84), 648 (3.82). ${ }^{1} \mathrm{H}$ NMR $\delta_{\mathrm{H}}$ ppm: 8.83-8.92 (m, 8H, $\beta-\mathrm{H}), 8.20-8.27$ (m, 6H, o-H-Ph), 8.18 (d, 2H, J=8.3 Hz, 2', 6'-HAr), 8.12 (bs, 1H, NH), 7.81 (d, 2H, J=8.3 Hz, 3', 5'-H-Ar), 7.727.80 (m, 9H, $m, p-\mathrm{H}-\mathrm{Ph}), 7.35-7.48$ (m, 5H, Ph-Phe), 5.28 (bs, 1H, $\mathrm{NH}), 4.68$ (bs, 1H, CH-Phe), 3.33 (d, 2H, J=6.0 Hz, CH2-Phe), 1.55 $(\mathrm{s}, 9 \mathrm{H}, t \mathrm{Bu}),-2.72$ (bs, 2H, NH).

5-[4'-(N-tert-Butyloxycarbonyl-L-leucylamido) phenyl]10,15,20-triphenylporphine $\mathbf{4 c}$. The porphyrin $\mathbf{4 c}$ was obtained using general procedure from $50 \mathrm{mg}(0.08 \mathrm{mmol})$ of porphyrin 3, $40 \mathrm{mg}(0.171 \mathrm{mmol})$ of $N$-tert-butyloxycarbonyl- $D$-leucine, $10 \mathrm{mg}(0.085 \mathrm{mmol})$ of DMAP and $130 \mathrm{mg}(0.684 \mathrm{mmol})$ of EDC. The reaction time was 3 days. Yield: $50 \mathrm{mg}(74.7 \%) . R_{f}=0.79$ (benzene:methanol=10:1). MS (MALDI TOF) $\mathrm{m} / \mathrm{z}$ : Calc. 842.39 for $\mathrm{C}_{55} \mathrm{H}_{50} \mathrm{~N}_{6} \mathrm{O}_{3}$. Found $843.4480[\mathrm{M}+\mathrm{H}]^{+}$. IR $v \mathrm{~cm}^{-1}: 1640(\mathrm{CONH})$. UV-Vis $\lambda_{\text {max }}(\lg \varepsilon) \mathrm{nm}: 420$ (5.68), 517 (4.30), 552 (4.04), 591 (3.88), 648 (3.87). ${ }^{1} \mathrm{H}$ NMR $\delta_{\mathrm{H}}$ ppm: 8.80-8.93 (m, 8H, $\left.\beta-\mathrm{H}\right), 8.74$ (bs, $1 \mathrm{H}$, $\mathrm{NH}), 8.23$ (d, 2H, $J=7.3 \mathrm{~Hz}, 2^{\prime}, 6$ '-H-Ar), 8.20 (d, 6H, $J=7.8 \mathrm{~Hz}$, $o-\mathrm{H}-\mathrm{Ph}$ ), 7.98 (d, 2H, J=7.3 Hz, 3',5'-H-Ar), 7.66-7.82 (m, 9H, $m, p-\mathrm{H}-\mathrm{Ph}$ ), 5.07 (bs, 1H, NH), 4.45 (bs, 1H, CH-Leu), 1.96-2.04 $\mathrm{m}, 1.86-1.96\left(\mathrm{~m}, 2 \times 1 \mathrm{H}, \mathrm{CH}_{2}-\mathrm{Leu}\right), 1.59(\mathrm{~s}, 9 \mathrm{H}, \mathrm{H}-\mathrm{tBu}), 1.11(\mathrm{t}, 6 \mathrm{H}$, $J=6.6 \mathrm{~Hz}, \mathrm{CH}_{3}$-Leu), -2.75 (bs, $2 \mathrm{H}, \mathrm{NH}$ ).

5-[4'-(N-tert-Butyloxycarbonyl-D-leucylamido)phenyl]10,15,20-triphenylporphine $4 \boldsymbol{d}$. The porphyrin $4 \mathbf{d}$ was obtained using general procedure from $50 \mathrm{mg}(0.08 \mathrm{mmol})$ of porphyrin 3, $40 \mathrm{mg}(0.171 \mathrm{mmol})$ of $N$-tert-butyloxycarbonyl- $D$-leucine, $11 \mathrm{mg}(0.09 \mathrm{mmol})$ of DMAP and $131 \mathrm{mg}(0.686 \mathrm{mmol})$ of EDC. The reaction time was 3 days. Yield: $47 \mathrm{mg}(69.9 \%) . R_{f}=0.79$ (benzene:methanol=10:1). MS (MALDI TOF) $\mathrm{m} / \mathrm{z}$ : Calc. 842.39 for $\mathrm{C}_{55} \mathrm{H}_{50} \mathrm{~N}_{6} \mathrm{O}_{3}$. Found $843.4473[\mathrm{M}+\mathrm{H}]^{+}$. IR $v \mathrm{~cm}^{-1}$ : $1634(\mathrm{CONH})$. UV-Vis $\lambda_{\text {max }}(\lg \varepsilon) \mathrm{nm}: 420$ (5.69), 516 (4.31), 554 (4.03), 592 (3.89), 647 (3.86). ${ }^{1} \mathrm{H}$ NMR $\delta_{\mathrm{H}}$ ppm: 8.80-8.93 (m, 8H, $\left.\beta-\mathrm{H}\right), 8.77$ (bs, 1H, NH), 8.23 (d, 2H, J=7.4 Hz, 2',6'-H-Ar), 8.15-8.23 (m, 6H, $o$-H-Ph), 7.98 (d, 2H, J=7.4 Hz, 3',5'-H-Ar), 7.68-7.83 (m, 9H, $m, p-\mathrm{H}-\mathrm{Ph}$ ), 5.09 (bs, 1H, NH), 4.46 (bs, 1H, CH-Leu), 1.96-2.04 $\mathrm{m}, 1.87-1.96\left(\mathrm{~m}, 2 \times 1 \mathrm{H}, \mathrm{CH}_{2}-\mathrm{Leu}\right), 1.59(\mathrm{~s}, 9 \mathrm{H}, \mathrm{H}-t \mathrm{Bu}), 1.11$ (t, $6 \mathrm{H}$, $\left.J=6.5 \mathrm{~Hz}, \mathrm{CH}_{3}-\mathrm{Leu}\right),-2.75$ (bs, $\left.2 \mathrm{H}, \mathrm{NH}\right)$.

5-[4'-(N-tert-Butyloxycarbonyl-L-isoleucylamido)phenyl]10,15,20-triphenylporphine $4 \boldsymbol{e}$. The porphyrin $4 \mathrm{e}$ was obtained by general procedure from $50 \mathrm{mg}(0.08 \mathrm{mmol})$ of porphyrin 3 , $40 \mathrm{mg}(0.171 \mathrm{mmol})$ of $N$-tert-butyloxycarbonyl- $L$-isoleucine, $11 \mathrm{mg}(0.09 \mathrm{mmol})$ of DMAP and $99 \mathrm{mg}(0.517 \mathrm{mmol})$ of EDC. The reaction time was 3 days. Yield: $48 \mathrm{mg}(71.8 \%) . R_{f}=0.58$ (benzene:methanol=10:1). MS (MALDI TOF) $\mathrm{m} / \mathrm{z}$ : Calc. 842.39 for $\mathrm{C}_{55} \mathrm{H}_{50} \mathrm{~N}_{6} \mathrm{O}_{3}$. Found $843.2987[\mathrm{M}+\mathrm{H}]^{+}$. IR $v \mathrm{~cm}^{-1}: 1640(\mathrm{CONH})$. $\mathrm{UV}-\mathrm{Vis} \lambda_{\max }(\lg \varepsilon) \mathrm{nm}: 420(5.70), 517$ (4.31), $552(4.04), 592(3.87)$, 648 (3.85). ${ }^{1} \mathrm{H}$ NMR $\delta_{\mathrm{H}}$ ppm: $8.80-8.92(\mathrm{~m}, 8 \mathrm{H}, \beta-\mathrm{H}), 8.44(\mathrm{bs}$,
$1 \mathrm{H}, \mathrm{NH}), 8.24$ (d, 2H, J=7.4 Hz, 2',6'-H-Ar), 8.15-8.23 (m, 6H, $o-\mathrm{H}-\mathrm{Ph}$ ), 7.98 (d, 2H, J=7.4 Hz, 3',5'-H-Ar), 7.68-7.82 (m, 9H, $m, p-\mathrm{H}-\mathrm{Ph}$ ), 5.26 (bs, 1H, NH), 4.28 (t, 1H, J=7.5 Hz, CH-Ile), 1.77 (bs, 1H, CH-Ile), $1.58(\mathrm{~s}, 9 \mathrm{H}, t \mathrm{Bu}), 1.30-1.41$ (m, 2H, $\mathrm{CH}_{2}$-Ile), 1.20 (d, $3 \mathrm{H}, J=6.7 \mathrm{~Hz}, \mathrm{CH}_{3}$-Ile), 1.08 (t, $3 \mathrm{H}, J=7.4 \mathrm{~Hz}, \mathrm{CH}_{3}$ ), -2.75 (bs, 2H, NH).

Synthesis of $Z n$ complexes $\mathbf{5 a - e}$. Generally 1 eq. of porphyrin 4a-e was refluxed with 100 eqs. of $\mathrm{Zn}$ acetate in DMF during $2 \mathrm{~h}$. Reaction was controlled with UV-Vis spectra. After cooling to room temperature the reaction mixture was added to ice water, the porphyrin 5a-e filtered off, washed thoroughly with water and dried under vacuum.

5a. MS (MALDI TOF) $m / z$ : Calc. 848.25 for $\mathrm{C}_{51} \mathrm{H}_{40} \mathrm{~N}_{6} \mathrm{O}_{3} \mathrm{Zn}$. Found 848.4938 M+. UV-Vis (DMF) $\lambda_{\text {max }} \mathrm{nm}: 426,558,597$.

5b. MS (MALDI TOF) $m / z$ : Calc. 938.29 for $\mathrm{C}_{58} \mathrm{H}_{46} \mathrm{~N}_{6} \mathrm{O}_{3} \mathrm{Zn}$. Found $938.5413 \mathrm{M}^{+}$. UV-Vis (DMF) $\lambda_{\text {max }} \mathrm{nm}: 426,558,597$.

5c. MS (MALDI TOF) $m / z$ : Calc. 904.31 for $\mathrm{C}_{55} \mathrm{H}_{48} \mathrm{~N}_{6} \mathrm{O}_{3} \mathrm{Zn}$. Found $904.6473 \mathrm{M}^{+}$. UV-Vis (DMF) $\lambda$ nm: 426, 558, 600 .

5d. MS (MALDI TOF) $m / z$ : Calc. 904.31 for $\mathrm{C}_{55} \mathrm{H}_{48} \mathrm{~N}_{6} \mathrm{O}_{3} \mathrm{Zn}$. Found $904.6093 \mathrm{M}^{+}$. UV-Vis (DMF) $\lambda_{\max } \mathrm{nm}: 426,558,599$.

5e. MS (MALDI TOF) $m / z$ : Calc. 904.31 for $\mathrm{C}_{55} \mathrm{H}_{48} \mathrm{~N}_{6} \mathrm{O}_{3} \mathrm{Zn}$. Found $904.6178 \mathrm{M}^{+}$. UV-Vis (DMF) $\lambda_{\text {max }} \mathrm{nm}: 426,558,600$.

\section{Results and Discussion}

\section{Synthesis of the porphyrin-amino acid conjugates}

Low symmetrical aminophenylporphyrin 3 was obtained from $\mathrm{H}_{2}$ TPP (1) by two steps (Scheme 1). Firstly, $\mathrm{H}_{2}$ TPP was regioselective nitrated using equimolar amounts of the sodium nitrite and $\mathrm{H}_{2}$ TPP in triflouracetic acid by stirring at $0{ }^{\circ} \mathrm{C}$ as described by us earlier. ${ }^{[16]}$ The reduction of nitro group in porphyrin 2 was carried out with $\mathrm{SnCl}_{2} \cdot 2 \mathrm{H}_{2} \mathrm{O}$ in concentrated $\mathrm{HCl}$ by heating of the reaction mixture at $65{ }^{\circ} \mathrm{C}$ during $1 \mathrm{~h}$. Column chromatography on silica gel for purification of both porphyrins $\mathbf{2}$ and $\mathbf{3}$ was used. The target conjugates 4 were synthesized by condensation of Boc-protected amino acids with aminophenylporphyrin 3. Since the early works on the synthesis of porphyrin-amino acid conjugates, different synthetic approaches, such as the DCC and HBTU method, have been trying. DCC method is commonly used for this coupling reaction.

Nevertheless, this approach takes a lot of time and much more complicated because of the purification from dicyclohexylurea (DCHU) formed in the reaction. We established that column chromatography on silica without separation from DCHU does not give pure desired porphyrins because of the same mobility both porphyrin-amino acid conjugates and DCHU in silica column. To overcome this problem, the coupling reaction was achieved by activating the carboxylic group in Boc-protected amino acids with 1-(3-dimethylaminopropyl)-3-ethylcarbodiimide hydrochloride (EDC). The coupling reactions were carried out in DCM in presence $N, N$-dimethylaminopyridine (DMAP) as a catalyst first at $0{ }^{\circ} \mathrm{C}$ and then at room temperature during up to 3 days. All the procedure was very easy - after reaction time, the solvent was evaporated to dryness and crude product was purified by column chromatography using DCM as eluent with small amounts (up to $1 \%$ ) of methanol. Using this synthetic route, the desired porphyrin-amino acid conjugates 4 a-e were obtained in $70-83 \%$ yields. The long- 


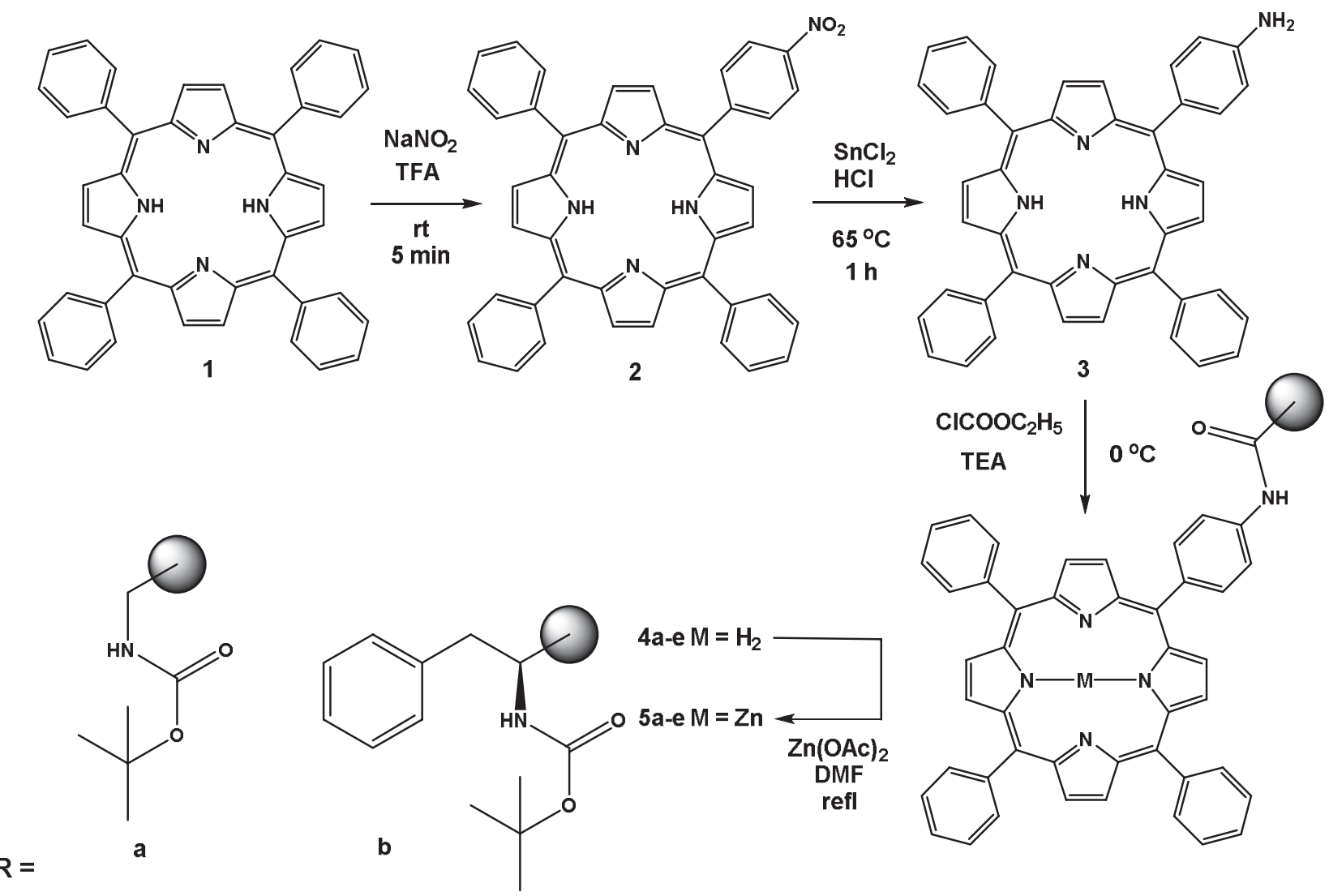<smiles>CC(C)C[C@H](NC(=O)OC(C)(C)C)c1ccccc1</smiles>

c<smiles>CC(C)C[C@H](NC(=O)OC(C)(C)C)c1ccccc1</smiles>

d<smiles>CC[C@H](C)[C@H](NC(=O)OC(C)(C)C)C(C)(C)C</smiles>

e

Scheme 1.

continued reaction is the second sophisticated factor for this method. We studied influence of the activating agent nature on reaction time of aminophenylporphyrin 3 with Boc-glycine in detail. Firstly, no noticeable differences in the conditions and results of the reaction were found when EDC was used instead of DCC. We also accepted that the temperature control, especially on the activation stage of the carboxylic group, is very important. The yield of amidoporphyrin 4a was near $50 \%$ when the reaction was carried out each time at room temperature. The longer coupling reaction (up to 7 days) and the using of the periodical ultra-sonic conditions did not give better yield of $\mathbf{4 a}$. We find out, that precooling of the reaction mixture at $0{ }^{\circ} \mathrm{C}$ before addition of the porphyrin $\mathbf{3}$ and stirring at the same temperature for maximum $1 \mathrm{~h}$ and further stirring at room temperature overnight give the porphyrin 4a with $75 \%$ yield. As described in literature ${ }^{[5,11]}$ ethyl chloroformate is more effective as activating agent for carboxylic group coupling reaction especially to form porphyrin-amino acid tetraconjugates. The activation of Boc-glycine with ethyl chloroformate in DCM in presence of TEA at $0{ }^{\circ} \mathrm{C}$ before addition of the porphyrin 3 and further stirring of the reaction mixture at the same temperature overnight gives desired porphyrin $4 \mathbf{a}$ in almost quantitative yield. Finally, the $\mathrm{Zn}$ complexes 5a-e were prepared in good yield using modified protocol ${ }^{[18]}$ by refluxing 100 eqs. of $\mathrm{Zn}$ acetate and 1 eq. of corresponding free ligand in DMF. Zinc complex formation was monitored spectrophotometrically.

\section{Characterization of the porphyrin derivatives}

${ }^{1} \mathrm{H}$ NMR, MALDI-TOF, UV-Vis and IR were obtained for characterization of free porphyrins and $\mathrm{Zn}$ complexes. The free base porphyrins 4a-e show typical UV-Vis spectra, with a Soret band near $420 \mathrm{~nm}$ and four less intense visible $Q$-bands at approximately 516, 552, 591 and $648 \mathrm{~nm}$ (Table 1) in $\mathrm{CHCl}_{3}$. As shown in Table 1, addition of the amino acid fragment to peripheral amino group of porphyrin 3 did 
not affect on the all absorption bands position. Insertion of the metal ion into the porphyrin core leads to the typical changes in the absorption spectra. The results are in good agreement with the literature. ${ }^{[19]}$

Table 1. UV-Vis absorption spectra of porphyrin conjugates.

\begin{tabular}{ccc}
\hline Porphyrins & Soret band & $Q$ band \\
\hline $\mathbf{3}$ & 421 & $516,554,592,648$ \\
$\mathbf{4 a}$ & 418 & $516,551,591,647$ \\
$\mathbf{4 b}$ & 420 & $517,554,591,648$ \\
$\mathbf{4 c}$ & 420 & $517,552,592,648$ \\
$\mathbf{4 d}$ & 420 & $516,554,592,647$ \\
$\mathbf{4 e}$ & 420 & $517,552,592,648$ \\
$\mathbf{5 a}$ & 426 & 558,597 \\
$\mathbf{5 b}$ & 426 & 558,597 \\
$\mathbf{5 c}$ & 426 & 558,600 \\
$\mathbf{5 d}$ & 426 & 558,599 \\
$\mathbf{5 e}$ & 426 & 558,600 \\
\hline
\end{tabular}

The peaks corresponded to the $[\mathrm{M}+\mathrm{H}]^{+}$ion for all free base porphyrins 4a-e and peaks of the $\mathrm{M}^{+}$ion of their $\mathrm{Zn}$ complexes 5a-e in MALDI TOF spectra were found with other less intensive peaks characterized as example for $[\mathrm{M}+\mathrm{Na}]^{+}$ions (all free base) and in some cases for ions without Boc-protected groups $[\mathrm{M}-100]^{+}$(5a-d).

The position and integration of proton signals in the ${ }^{1} \mathrm{H}$ NMR spectra (experimental section) clearly confirm the structure of synthesized compounds.

\section{Fluorescence quantum yield}

All investigated porphyrins and their $\mathrm{Zn}$ complexes are characterized by intense fluorescence (Figure S1). Fluorescence quantum yields were determined using $\mathrm{H}_{2}$ TPP in DMF as a standard $\left(\Phi_{\mathrm{F}}=0.11\right)$ for free porphyrin ligands at the excitation wavelength $420 \mathrm{~nm}$, and using ZnTPP in DMF as a standard $\left(\Phi_{\mathrm{F}}=0.033\right)$ for their $\mathrm{Zn}$ complexes

Table 2. Fluorescence peak values and fluorescence quantum yields of the porphyrin conjugates.

\begin{tabular}{cccc}
\hline Porphyrin & $\lambda_{\text {excitation }}, \mathrm{nm}$ & $\lambda_{\max }$ emission, $\mathrm{nm}$ & $\Phi_{\mathrm{F}}$ \\
\hline $\mathrm{H}_{2} \mathrm{TPP}$ & 420 & 653,714 & 0.110 \\
$\mathbf{4 a}$ & 420 & 655,716 & 0.100 \\
$\mathbf{4 b}$ & 420 & 656,716 & 0.108 \\
$\mathbf{4 c}$ & 420 & 656,716 & 0.104 \\
$\mathbf{4 d}$ & 420 & 656,716 & 0.101 \\
$\mathbf{4 e}$ & 420 & 656,716 & 0.103 \\
$\mathrm{ZnTPP}$ & 428 & 614,664 & 0.033 \\
$\mathbf{5 a}$ & 428 & 610,660 & 0.036 \\
$\mathbf{5 b}$ & 428 & 609,660 & 0.035 \\
$\mathbf{5 c}$ & 428 & 609,660 & 0.035 \\
$\mathbf{5 d}$ & 428 & 609,660 & 0.036 \\
$\mathbf{5 e}$ & 428 & 609,660 & 0.034 \\
\hline
\end{tabular}

at the excitation wavelength $428 \mathrm{~nm}$. Calculated values are quite similar with standard ones (Table 2), so there is no significant influence of amino-acid groups on studied conjugates fluorescence quantum yield.

\section{Photostability of the porphyrin conjugates}

The rate of compounds photodegradation under light conditions is a key parameter of their potential application

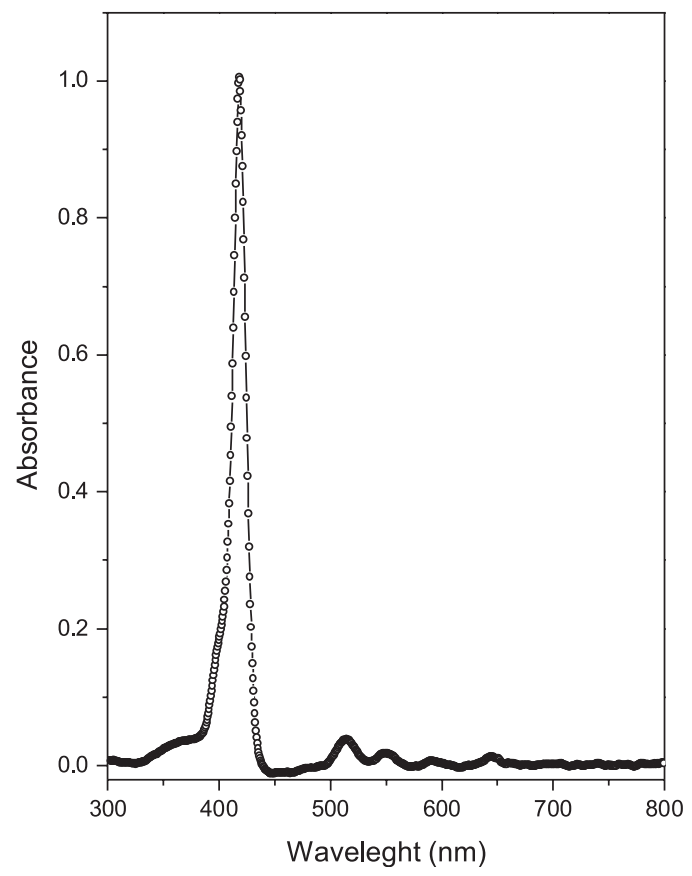

Figure 1. UV-Vis absorption spectra of $\mathbf{4 a}$ in DMF before irradiation (-) and after 1 hour of irradiation with white light (०).

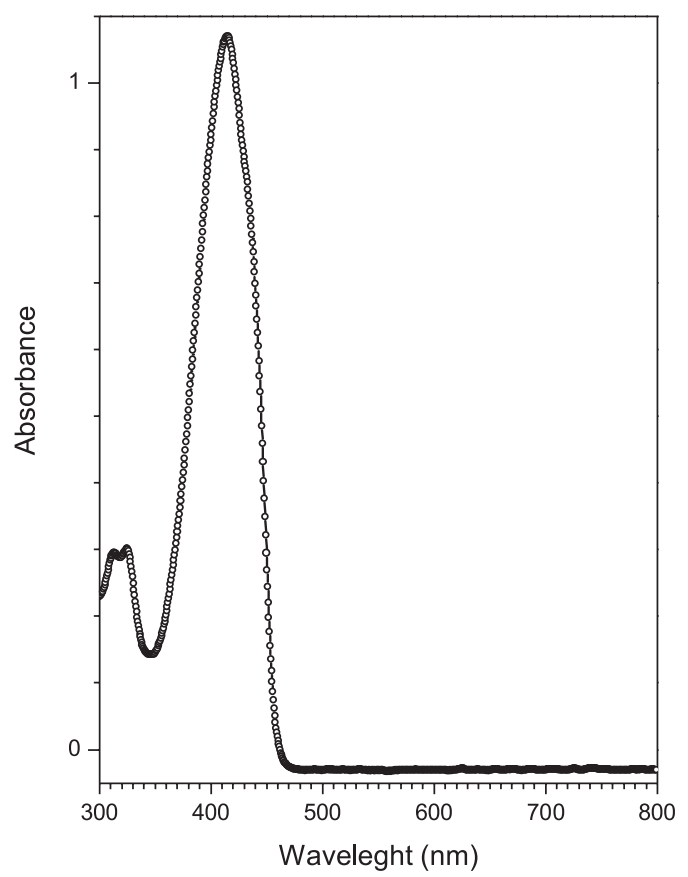

Figure 2. UV-Vis absorption spectra of DPBF in DMF without photosensitizer before irradiation $(-)$ and after 1 hour of irradiation with white light using cut-off filter $\lambda<500 \mathrm{~nm}(\circ)$. 

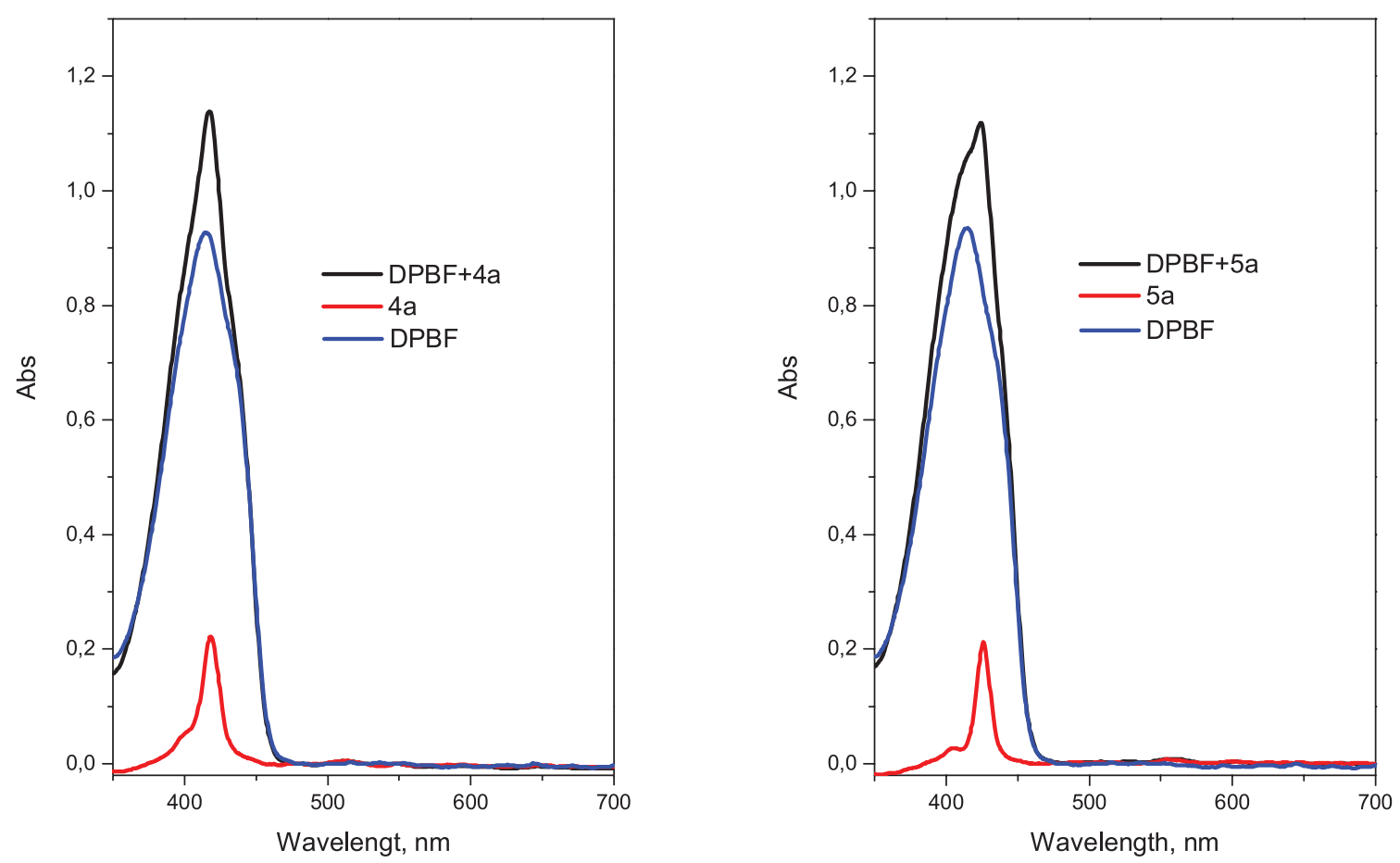

Figure 3. UV-Vis absorption spectra of $\mathbf{4 a}$, DPBF and their mixture in DMF (left) and $\mathbf{5 a}$, DPBF and their mixture in DMF (right).

as photosensitizers. All photosensitizer's photostabilities were determined in DMF solutions, absorbance at Soret band wavelength was 1 . Obtained results demonstrated high photostabily of all investigated compounds under irradiation with white light during at least 1 hour. UV-Vis absorption spectra of $\mathbf{4} \mathbf{a}$ before and after irradiation are shown in Figure 1 as an example.

\section{Singlet oxygen generation studies}

Considering the potential application of the porphyrinamino acid conjugates $\mathbf{4 a - e}$ and their $\mathrm{Zn}$ complexes 5a-e as photosensitizers in PDT, we made a qualitative evaluation of their ability to generate singlet oxygen by monitoring the photodecomposition of DPBF. Using a light filter with $\lambda<500 \mathrm{~nm}$ allows to completely cut off the region of DPBF absorption. Irradiation of the DPBF solution with white light with a cut-off filter with $\lambda<500 \mathrm{~nm}$ does not produce any visible changes in UV-Vis spectrum for at least 1 hour (Figure 2).

The ability of compounds $\mathbf{4 a - e}$ and their $\mathrm{Zn}$ complexes 5a-e to singlet oxygen generation was investigated in aerated systems, containing equal volumes $(1 \mathrm{ml})$ of $\mathrm{DPBF}(\mathrm{OD}=2.0$ at the irradiation wavelength) and photosensitizer $(\mathrm{OD}=0.4$ at the Soret wavelength) (Figure 3). The photodecomposition of DPBF was monitored by measuring the decreasing of the absorbance at $416 \mathrm{~nm}$ corrected by the absorbance of the photosensitizer at the corresponding detection wavelength.

The DPBF photodegradation is observed in the presence of all the photosensitizers (Figures 4-7, S15-18, S2023 ) and the decay curves of all the compounds are quite comparable to $\mathrm{H}_{2}$ TPP and ZnTPP, which were used as the references (Figures S14,19).

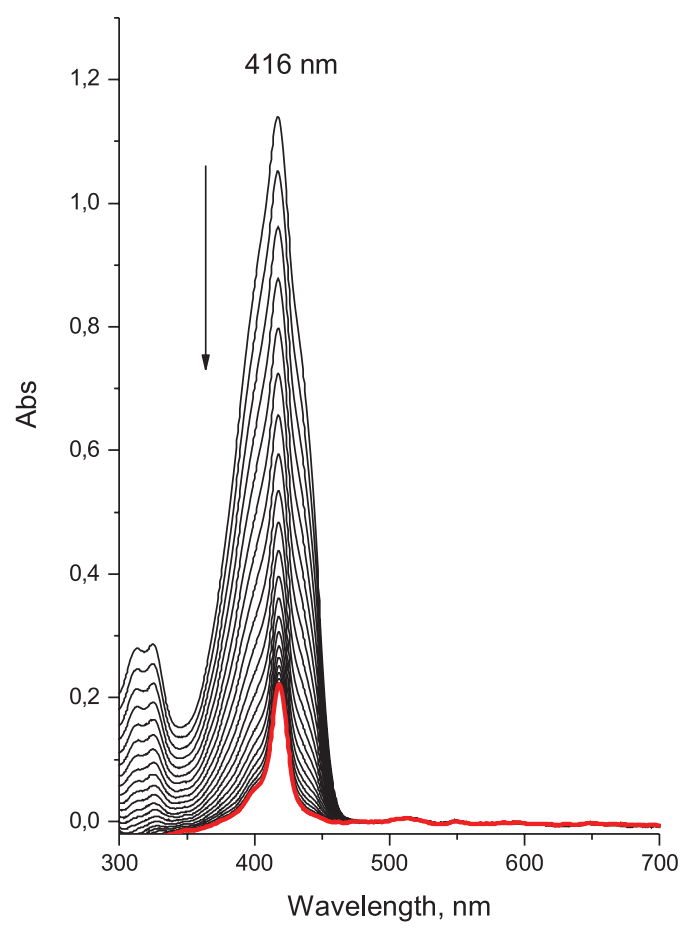

Figure 4. Spectral changes in the reaction mixture of $\mathbf{4 a}$ and DPBF in DMF under irradiation with white light filtered through a cut-off filter $\lambda<500 \mathrm{~nm}$.

DPBF decay rate is higher in the presence of the all investigated $\mathrm{H}_{2}$ TPP amino acids conjugates, which means a higher efficiency of singlet oxygen generation by these photosensitizers under the same experimental conditions. The maximum photodecomposition rate of DPBF is observed in the presence of photosensitizer $\mathbf{4 a}$. 


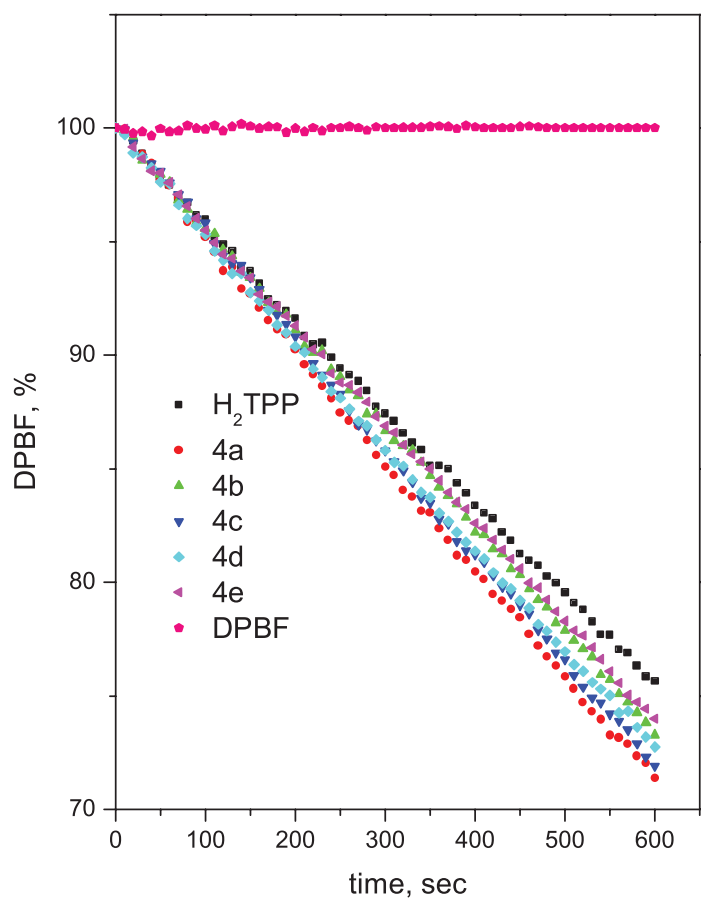

Figure 5. Decay curves for DPBF in the presence of $\mathrm{H}_{2}$ TPP conjugates under irradiation with white light filtered through a cut-off filter $\lambda<500 \mathrm{~nm}$, upper line - DPBF test solution without photosensitizer.

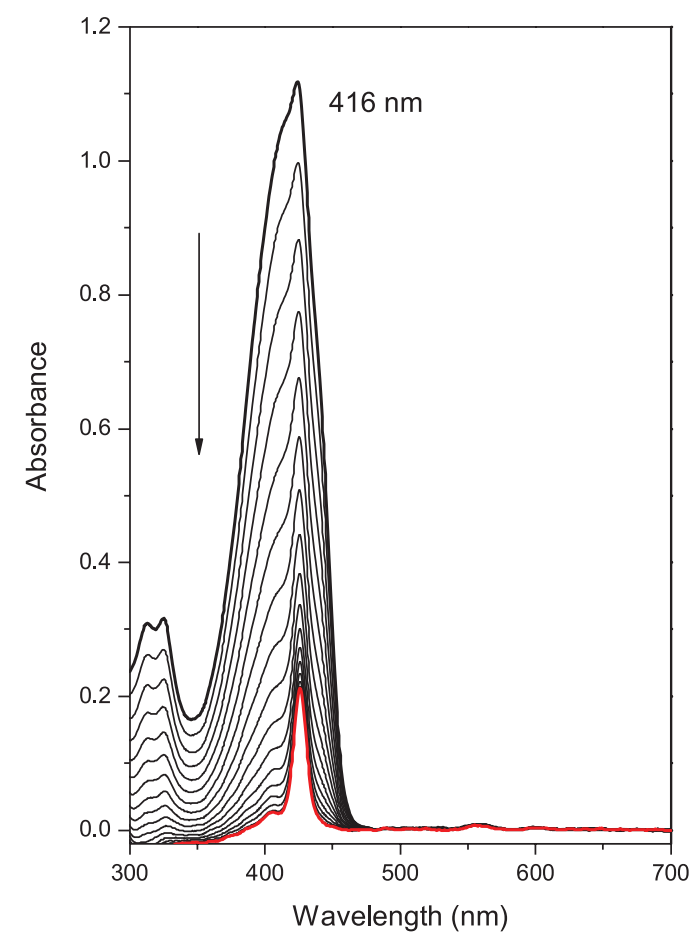

Figure 6. Spectral changes in the reaction mixture of $\mathbf{5 a}$ and DPBF in DMF under irradiation with white light filtered through a cut-off filter $\lambda<500 \mathrm{~nm}$.

The macrocyclic metal complexes with zinc as central metal ion are most interesting for PDT because they show high values for the triplet state lifetime and exhibit the best singlet oxygen quantum yield. ${ }^{[20]}$ The ability of zinc porphy-

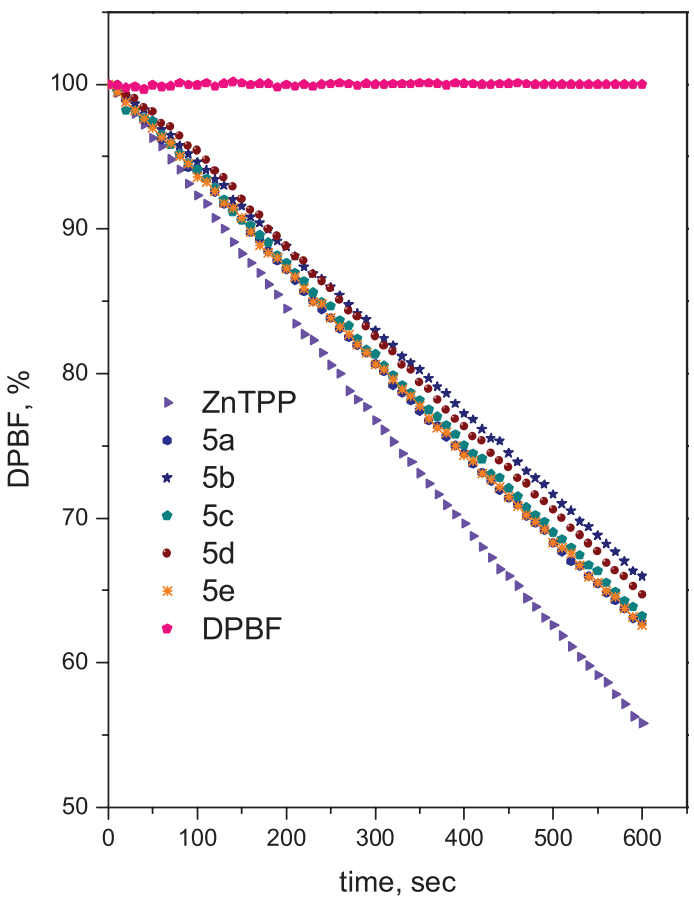

Figure 7. Decay curves for DPBF in the presence of ZnTPP conjugates under irradiation with white light filtered through a cut-off filter $\lambda<500 \mathrm{~nm}$, upper line - DPBF test solution without photosensitizer.

rinates $\mathbf{5 a - e}$ to generate singlet oxygen was also investigated using the same procedure as described for free porphyrin ligands.

As expected, DPBF decay rate is higher in the presence of the ZnTPP-amino acids conjugates as compared with their nonmetallic analogues, which means a higher efficiency of singlet oxygen generation by these photosensitizers under the same experimental conditions.

\section{Conclusions}

In summary, we have synthesized a series of low symmetrical porphyrins substituted with Boc-protected glycine, $L$-phenylalanine, $L$ - and $D$-leucine and $L$-isoleucine. We have found that coupling reaction of the aminoporphyrin 3 with Boc-glycine as an example gives desired conjugate 4a in almost quantitative yield by activating the carboxylic group with ethyl chloroformate. All investigated porphyrinamino acid conjugates show a higher efficiency to generate singlet oxygen than $\mathrm{H}_{2} \mathrm{TPP}$ under the same experimental conditions.

Acknowledgements. The authors gratefully acknowledge the support of the Russian Science Foundation (project No. 16-13-10453).

\section{References}

1. Ali H., Van Lier J.E. Chem. Rev. 1999, 99, 2379.

2. Vatansever F., Melo W.C., Avci P., Vecchio D., Sadasivam M., 
Gupta A., Chandran R., Karimi M., Parizotto N.A., Yin R. FEMS Microbiol. Rev. 2013, 37, 955-989.

3. Maisch T. Mini-Rev. Med. Chem. 2009, 9, 974-983.

4. Cavaleiro J.A.S., Faustino M.A., Tomé J.P.C. In: Carbohydrate Chemistry (Rauter A.P., Lindhorst T.K., Eds.) Cambridge: Publishing, 2009, Vol. 35, p. 199-227.

5. Meng S., Xu Z., Hong G., Zhao L., Zhao Z., Guo J., Ji H., Liu T. Eur. J. Med. Chem. 2015, 92, 35-48.

6. $\quad$ Chaleix V., Sol V., Krausz P. Tetrahedron Lett. 2011, 52, $2977-$ 2979.

7. Serra V.V., Zammarŕon A., Faustino M.A.F., Iglesias-de la Cruz M.C., BlázquezA., Rodrigues J.M.M., Neves M.G.P.M.S., Cavaleiro J.A.S., Juarranz A., Sanz-Rodriguez F. Bioorg. Med. Chem. 2010, 18, 6170-6178.

8. Wang H.M., Jiang J.Q., Xiao J.H., Gao R.L., Lin F.Y., Liu X.Y. Chem. Biol. Interact. 2008, 172, 154-158.

9. Shi W., Zhang G., Dai G., Zhang Y., Zhao J., Tao J. Bioorg. Med. Chem. 2008, 16, 5665-5671.

10. Sol V., Blais J.C., Carré V., Guilloton M., Spiro M., Krausz P. J. Org. Chem. 1999, 64, 4431-4444.
11. Biron E., Voyer N. Chem. Commun. 2005, 4652-4654.

12. Marder O., Albericio F. Chimica Oggi-Chemistry Today 2003, 21, 6-11.

13. Managa M., Ngoy B.P., Nyokong T. J. Photochem. Photobiol., A: Chemistry 2017, 339, 49-58.

14. Ermilov E.A., Sebastian T., Werncke T., Choi M.T.M., Ng D.K.P., Röder B. Chem. Phys. 2006, 328, 428-437.

15. Brookfield R.L., Ellul H., Harriman A., Porter G. J. Chem. Soc., Faraday Trans. 2 1986, 82, 219-233.

16. Lebedeva N.Sh., Gubarev Y.A., Yurina E.S., Smirnova E.N., Syrbu S.A. Colloid Polym Sci. 2017, 295, 2173-2182.

17. Salnikova M.A., Lubimova T.V., Glazunov A.V., Syrbu S.A., Semeikin A.S. Macroheterocycles 2014, 7, 249-255.

18. Alder A.D., Low F.R., Kampas F., Kim J. J. Inorg. Nucl. Chem. 1970, 32(7), 2443-2445.

19. Sternberg E.D., Dolphin D., Bröuckner C. Tetrahedron 1998, $54,4151$.

20. Moser J.G. Photodynamic Tumor Therapy. $2^{\text {nd }}$ and $3^{\text {rd }}$ Generation Photosensitizers. Amsterdam: Harwood Academic Publishers, 1998. 242 p. 